\title{
Morphological and molecular parameters for the characterization of accessions of pepper with ornamental potential
}

\author{
S. Pimenta ${ }^{1}$, W.S. Gomes ${ }^{1}$, B.R.A Rodrigues ${ }^{1}$, L.B Jardim ${ }^{1}$, \\ A.M.P.B do Vale', S.A. de Souza ${ }^{2}$, H.C.F. Monteiro' ${ }^{1}$, C.S. Bento ${ }^{3}$ and \\ I.N.R. Santos ${ }^{1}$ \\ ${ }^{1}$ Departamento de Ciências Agrárias, Universidade Estadual de Montes \\ Claros, Janaúba, Minas Gerais, Brazil \\ 2 Faculdade do Vale do Gorutuba, Nova Porteirinha, Minas Gerais, Brazil \\ ${ }^{3}$ Departamento de Agronomia, Universidade Federal do Espírito Santo, \\ Alegre, Espírito Santo, Brazil
}

Corresponding author: B.R.A Rodrigues

E-mail: agrobr@outlook.com

Genet. Mol. Res. 19 (2): gmr18596

Received March 24, 2020

Accepted May 29, 2020

Published June 30, 2020

DOI http://dx.doi.org/10.4238/gmr18596

\begin{abstract}
Ornamental peppers have been attracting great commercial interest in recent years. However, despite the demand, the availability of ornamental pepper cultivars to growers and consumers is still reduced, which should stimulate breeding programs for improved varieties. In this context, the identification and characterization of accessions in ornamental pepper germplasm banks is extremely important. We phenotypically characterized nine pepper accessions and analyzed the genetic divergence between them for the potential development of ornamental pepper cultivars. The experiment was conducted in a greenhouse at the agricultural sciences center of the State University of Montes Claros, Minas Gerais, in a completely randomized design, with nine accessions and eight replications. The plants were morphologically characterized with 34 qualitative and five quantitative descriptors. For taxonomic identification to the species level, a key to identify Capsicum species was used. In the molecular analysis, 32 ISSR primers were used for the detection of polymorphism between individuals. A multivariate
\end{abstract}


analysis was performed by estimating the genetic dissimilarity by the Jaccard coefficient for the molecular variables and by the Gower algorithm for the morphological ones, using the UPGMA method for hierarchical analysis of clusters. The nine accessions that were selected for evaluation were considered as potential parents due to characteristics of ornamental interest. The accessions were all classified as belonging to the species Capsicum annuиm and were grouped differently when using morphological versus molecular data. Analysis of molecular data detected greater dissimilarity between accessions, with the formation of a larger number of groups. The joint exploration of the morphological and molecular information allows a more reliable inference of the genetic dissimilarity between accessions and will facilitate planning of crosses.

Key words: Breeding; Germplasm bank; Variability; Morphological descriptors; Molecular marker

\section{INTRODUCTION}

Due to interest in ornamental varieties, research on peppers (Capsicum spp.) has been intensified in recent years. One of the the main objectives pursued by researchers is to to obtain new cultivars with dual aptitude, ornamental and with edible fruits.

In Brazil there are only a few commercial cultivars of ornamental pepper being commercialized and, among these, there is little variation in the product, showing an open market niche (MAPA, 2017). There is considerable diversity in the Capsicum germplasm of the country, mainly regarding the shape and size of fruits and leaves, in addition to the growth habits of plants. This morphological diversity, combined with variation in fruit color, and varying shades of leaf pigmentation from green to purple, offers opportunities for the development of ornamental cultivars (Stommel and Bosland, 2007; dos Santos Pessoa et al., 2018; Ribeiro et al., 2020).

Studies aimed at characterizing and evaluating potential parents, thus estimating the diversity of an active germplasm bank (AGB), will assist genetic improvement programs in the development of new ornamental pepper cultivars. Thus, it becomes relevant to evaluate the ornamental potential of pepper accessions present in an AGB, to generate genetic information and make it available to breeding programs, enabling effective use.

There are several ways to provide data to infer an individual's genetic potential. Morphological and molecular characters are useful and should be considered simultaneously or individually at the time of genotypic selection. Studies, such as those of dos Santos Pessoa et al. (2019a) and da Luz et al. (2018) show the importance of a correct and complete evaluation of ornamental pepper genotypes for studies of genetic divergence and genetic selection. Costa et al. (2019), using only morphological evaluation, identified eight accessions of ornamental pepper with characters that could be explored commercially. However, a molecular approach would allow, in studies like this, an additional gain in the selection process. However, adequate knowledge of how to analyze and what to consider in genotypic evaluations, whether morphological or molecular, is needed. 
The pepper (Capsicum spp.) breeding program at the State University of Montes Claros (Unimontes) began in 2017 with the formation of an AGB for species of this genus. This AGB is composed of wild species, landrace varieties of pepper, peppers grown in homes and varieties sold in the local market, such as street fairs and supermarkets.

After evaluating the morphological characteristics of about 70 Capsicum accessions belonging to this AGB, nine were identified with potential for exploitation as ornamental peppers.

A complete characterization and evaluation of these accessions was carried out, at the molecular and morphological level, with the purpose of using such information for the ornamental pepper breeding program.

\section{MATERIAL AND METHODS}

\section{Implementation of the comparison and description of accessions}

The experiment was carried out in a greenhouse covered by $50 \%$ shade, located in an experimental area of the Unimontes, Campus Janaúba-MG, Brazil with a local altitude of $533 \mathrm{~m}$, with latitude of $15^{\circ} 48^{\prime} 09^{\prime \prime} \mathrm{S}$ and longitude of $43^{\circ} 18^{\prime} 32^{\prime \prime} \mathrm{N}$. The test was carried out from May to October 2018, totaling a period of six months.

Nine of the 70 accessions belonging to the Unimontes AGB of Capsicum were selected, based ornamental potential for cultivation in pots, and charateristics such as flower coloring, leaf, architecture, crown, and aspects involving one or more qualities, such as color, shape, brightness, texture, quantity, size and others.

The accessions were sown in plastic trays with 128 cells, filled with commercial Plantmax ${ }^{\circledR}$ substrate. Upon reaching the transplanting stage, from two to four pairs of definitive leaves, the seedlings were transplanted into one-liter pots, containing a mixture of soil, sand and bovine manure in the proportion of 1: 1: 1, respectively. After transplanting, the pots were distributed in a greenhouse in a completely randomized design, with eight replicates per accession, thus totaling 72 plants evaluated.

\section{Morphological analysis}

For the characterization of the accessions, descriptors recommended for species of the genus Capsicum were provided by the National Service of Plant Variety Protection (SNPC) an agency linked to the Ministry of Agriculture, Livestock and Food Supply. Altogether 39 descriptors were considered, which were evaluated from the period of seedlings to the harvest of the fruits (Table 1). Of these, five descriptors were evaluated quantitatively, namely: the length and width of the leaf blade, the length and diameter of the fruit and the thickness of the pericarp. For these, the measurements were made with the aid of a tape measure and / or caliper.

For the evaluation of the other descriptors, a side-by-side comparison was used, in which the distinction is based on the direct observation of the accessions. In this situation, there is no measurement. The characteristics were observed visually, granting, one grade per characteristic for each accession involved in the test. For the analysis of the descriptors related to the fruits, a total of five fruits per plant were observed, totaling 40 fruits per accession. 
For the taxonomic identification at the species level of accessions a key to identify species was used, classifying domesticated and semi-domesticated varieties of the genus Capsicum occurring in Brazil (Carvalho et al., 2006).

Table 1. Capsicum spp. morphological descriptors evaluated as recommended by the National Service for Plant Variety Protection in ornamental pepper accessions. Unimontes, Janaúba-MG, Brazil, 2020.

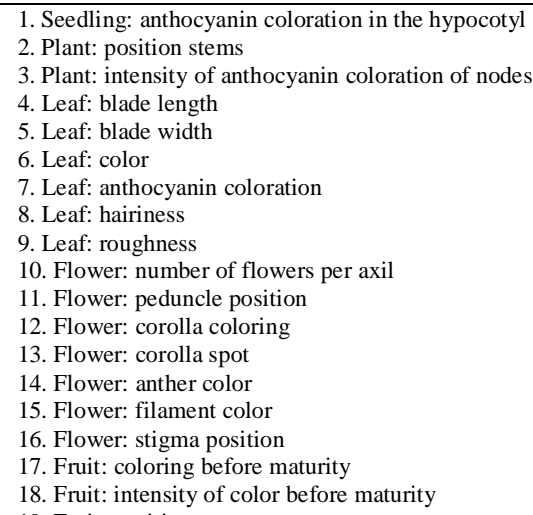

\section{Molecular analysis}

About $100 \mathrm{mg}$ of leaf tissue was macerated in liquid nitrogen, later transferred to $1.5 \mathrm{~mL}$ tubes and DNA extraction was started according to the protocol of Doyle and Doyle (1990), with modifications, described below. We added to the tubes containing the samples $800 \mu \mathrm{L}$ of the preheated extraction buffer containing $2 \% \mathrm{CTAB}, 1.4 \mathrm{M} \mathrm{NaCl}, 20 \mathrm{mM}$ EDTA, $100 \mathrm{mM}$ Tris- $\mathrm{HCl}$ (pH 8.0), $2 \%$ polyvinylpyrrolidone (PVP) and $0.2 \%$ mercaptoethanol. The tubes were vortexed gently and incubated in a water bath at $65^{\circ} \mathrm{C}$ for $30 \mathrm{~min}$. During incubation, the tubes were shaken gently every $10 \mathrm{~min}$. Then, $800 \mu \mathrm{L}$ of chloroform-isoamyl alcohol (24:1) was added and the tube was shaken by gentle inversions, for approximately five minutes, until turbid. Then, the samples were centrifuged at room temperature for $5 \mathrm{~min}$. The supernatant was transferred to a new tube and added to cold isopropanol (in a ratio of 1: 1 isopropanol: supernatant) and the tubes were inverted gently several times. The material was centrifuged at $14,000 \mathrm{rpm}$ for $10 \mathrm{~min}$ at room temperature. A white precipitate formed at the bottom of the tube. This precipitate was washed twice with $70 \%$ ethanol to remove the salt, and once with $95 \%$ ethanol. The precipitate was dried at room temperature for 15 to $20 \mathrm{~min}$.

After drying, the precipitate was resuspended in $100 \mu \mathrm{L}$ TE $(10 \mathrm{mM}$ Tris-HCl, 1 $\mathrm{mM}$ EDTA, $\mathrm{pH}$ 8.0). After this stage, the sample remained in the refrigerator for $24 \mathrm{~h}$ to guarantee the complete dissolution of the pellet.

The DNA quantification was determined using a spectrophotometer. DNA quality was assessed using the A260 / A280 $\mathrm{nm}$ ratio and in 0.8\% agarose gel.

For the detection of polymorphism between individuals, 32 ISSR primers were tested. The amplification reactions were conducted in a final volume of $13 \mu \mathrm{L}$, containing 
the following reagents: $5 \mathrm{ng}$ of genomic DNA, 0.75 unit of Taq DNA polymerase, $10 \mathrm{X}$ buffer $(20 \mathrm{mM} \mathrm{KCl}, 50 \mathrm{mM}$ Tris-HCl, $\mathrm{pH} 8.3), 2.5 \mathrm{mM} \mathrm{MgCl}_{2}$, dNTP (0.2 mM from each of the deoxyribonucleotides) and $0.5 \mu \mathrm{M}$ of each primer. $2 \mu \mathrm{L}$ of DNA were applied, and later, $11 \mu \mathrm{L}$ of the mix described above was added.

The amplification reactions (Techne thermal cycler, model T-512) were conducted as follows: $5 \mathrm{~min}$ at $94^{\circ} \mathrm{C}$ for initial denaturation, followed by 35 cycles, each consisting of $94^{\circ} \mathrm{C}$ for $1 \mathrm{~min}, 52^{\circ} \mathrm{C}$ for $1 \mathrm{~min}, 72^{\circ} \mathrm{C}$ for $3 \mathrm{~min}$ and a final extension at $72^{\circ} \mathrm{C}$ for $7 \mathrm{~min}$. The amplified fragments were then separated on a $1.5 \%$ agarose gel and submitted to ultraviolet light for visualization (Transiluminator UV - MultiDoc-It Imaging System - UVP). The images of the gels were captured for further analysis.

For population genotyping, only gels with clear band profiles were considered. Marks difficult to interpret were taken as lost data to avoid genotyping errors. Initially, genetic analysis was based on counting the presence (1) or absence (0) of the allele (band) per locus in the individuals.

\section{Statistical analysis}

For the analysis of the morphological descriptors, evaluated quantitatively, the frequency distribution of continuous variables in class intervals was used. The number of classes considered for each variable was proposed in the form for the protection of SNPC Capsicum cultivars. With these, the data was processed using descriptive statistics based on mode, which constitutes the most frequent value in a set of variables, of the marks attributed to each accession. For these analyzes, the Genes software was used (Cruz, 2016).

A multivariate analysis for each approach, molecular and morphological, was performed. For this, the genetic dissimilarity of the accessions was estimated by the Jaccard coefficient for the molecular variables and by the Gower algorithm for the morphological ones. For the formation of the dendrogram, the matrices of dissimilarity coefficients were analyzed using the medium link method between UPGMA groups (Unweighted Pair-Group Method of Arithmetic Averages). The cophenetic correlation coefficient (CCC) was estimated. As for the optimal number of groups formed in the dendrogram, the Mojena Method was used, adopting $\mathrm{k}=1.25$ as a stop rule in defining the number of groups.

A tanglegram was generated to illustrate the similarities and divergences between the associations of the two generated dendrograms, using the UPGMA method for hierarchical analysis of clusters. The rooted dendrograms (molecular and morphological) were designed opposite each other, using auxiliary lines to connect samples and establish a network of interactions. For all multivariate analyzes the software $\mathrm{R}$ version 3.5.2. was used, using the packages: H-Clust, Dendextend and RCMDR.

\section{RESULTS AND DISCUSSION}

\section{Morphological approach}

Among the 39 descriptors evaluated, 10 of these were identical for the nine accessions, representing an absence of variability for these characters (Tables 2, 3 and 4). This result is satisfactory, since, for most morphological descriptors, there is variability that 
can be explored, that is, parents with potential for ornamental exploration considering different characteristics.

Some descriptors, such as the absence of diffuse spots on the petals and isolated flowers in each node, are used for the taxonomic identification of the genus Capsicum at the species level (Baral and Bosland, 2002; Carvalho et al., 2006). Other descriptors, such as anthocyanin pigmentation in the hypocotyl and nodes, hairiness, stigma position, texture of the fruit surface, number of locus and ring constriction of the chalice are common characteristics found in the accessions, although they are not exclusive to the species $C$. annuиm (Moreira et al., 2006; Rodrigues et al., 2016).

In $C$. апnиum, one flower per node and the absence of spots on the corolla are typical characteristics of the species. Therefore, these descriptors enabled the identification of all accessions as belonging to $C$. annuum, with two $C$. annuum var. glabriusculum and five $C$. anпиum var. annuum (Figure 1).

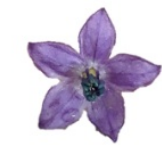

UNI 03

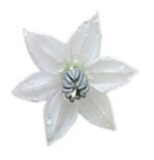

UNI 06

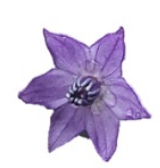

UNI 05

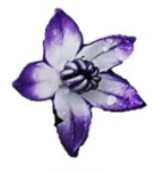

UNI 11

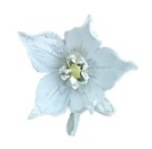

UNI 01

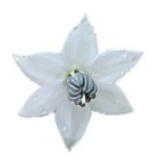

UNI 79

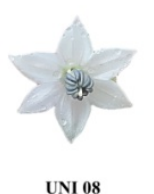

UNI 08

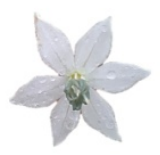

UNI 07

Figure 1. Flowers of ornamental pepper accessions: UNI 03 and UNI 05 (Capsicum annuum var. glabriusculum); UNI 11 and UNI 01 (C. annuum L.); UNI 06, UNI 07, UNI 08, UNI 79 and UNI 04 (C. annuиm var. annuum). Unimontes, Janaúba-MG, Brazil, 2020.

The genus Capsicum is classified into three gene complexes: the annuum complex (CA) includes the species $C$. annuum, C. chinense, C. frutescens and C. galapagoense. The baccatum complex (CB) contains $C$. baccatum, $C$. praetermissum and $C$. tovarii; and the pubescens complex (CP) consists of the species of $C$. pubescens, C. cardenasii, and $C$. eximium (Pickersgill, 1991). Because they belong to the same gene complex, all accessions identified in this work are suitable for crossing with each other. The same does not occur for crossing between different species complexes. Interspecific crossings between species of the same complex are relatively easy to be performed; however, although the barriers between gene complexes can be broken, this rarely occurs in nature (Walter et al., 2019).

The color of the anther varied between blue and violet (Table 2). Highlighting the accessions UNI 04, UNI 05 and UNI 79 with violet coloring. Sudré (2006) in a study of Capsicum spp. for another color, a predominance of blue color was observed, followed by purple and yellow anthers. Only accessions of $C$. апnиит had purple anthers, making the observation of this descriptor, allied to the others already mentioned for the identification of Capsicum species, important in this study. 
Table 2. Descriptors for flowers of Capsicum spp. according to the National Service of Protection of Cultivars). Janaúba-MG, Brazil, 2020.

\begin{tabular}{lllll}
\hline Access & $\mathbf{1 1}$ & $\mathbf{1 2}$ & $\mathbf{1 4}$ & $\mathbf{1 5}$ \\
\hline Uni 01 & Intermediate & White & Blue & White \\
Uni 03 & Intermediate & Violet & Blue & Violet \\
Uni 04 & Intermediate & White & Violet & White \\
Uni 05 & Intermediate & Violet & Violet & Violet \\
Uni 06 & Intermediate & White & Blue & White \\
Uni 07 & Pending & White & Blue & White \\
Uni 08 & Intermediate & White & White \\
Uni 11 & Intermediate & Violet & Blue & Violet \\
Uni 79 & Intermediate & White & Violet \\
\hline 11. Flower: peduncle position; 12. Flower:
\end{tabular}

(16. Flower: stigma position. Equal classes: 10. Number of flowers per axil: one; 13. Corolla spot: Absent.

A study by Melo et al. (2014) with ornamental pepper accessions found that all evaluated accessions had an upright floral position. There is variation for a characteristic that is somewhat disregarded and, to a certain extent, unknown to those who work with the species in conventional exploration. According to Ribeiro (2012) this is a desirable characteristic, as it is one of the first characteristics observed by floriculture professionals when choosing pepper trees with ornamental potential, due to this position leaving the flowers highlighted in the floral arrangement.

The accessions showed variation in the color of the corolla, this characteristic being of great ornamental interest, mainly because it makes the plant more attractive (Figure 1). Carvalho et al. (2006) reported that, in the ornamental pepper plant market, the descriptors corolla color, fruit color and shape are of great importance, in function of promoting contrast with the leaves of the plant. Despite the aesthetic value, according to Pickersgill (1997), the diversity of flower morphology in the Capsicum genus has been little explored. In addition, the morphological characteristics among others flower characteristics, are of great importance for species identification. It is noteworthy that the accessions UNI 03, UNI 05 and UNI 11 have flowers with corolla without the presence of spots, white with a purple border or totally purple, in addition to purple anthers. Such characteristics are typical of the species C. annuum var. glabriusculum (Viñals et al., 1996; Rodrigues et al., 2016; dos Santos Pessoa et al., 2019b). According to Moreira (2006), the species of the genus Capsicum can be distinguished by the morphological characteristics visualized in the flowers, in addition, it arouses great interest in the ornamental plants market for presenting characters that confer aesthetic value.

Through the quantitative evaluation, it was possible to distribute classes according to the recommendation proposed by the SNPC for Capsicum spp. Three distinct classes were obtained for the following characters: leaf blade length $(2.23-4.9 \mathrm{~cm}-$ short; 4.9 $7.57 \mathrm{~cm}$ - medium; 7.57 - 10.23 - long) and width leaf $(1.07-2.58 \mathrm{~cm}$ - narrow; 2.58 $4.09 \mathrm{~cm}$ - medium; $4.09-5.6 \mathrm{~cm}$ - wide) (Table 2). For these, only UNI 08 accession was distinct, with higher averages than the others. According to Santos (2012), leaf size is among the most important characteristics of plant size in ornamental pepper trees. Mainly because it influences the harmony of the crown, and small ornamental plants must have smaller leaves that are proportional to the crown.

Regarding the color of the leaves, the plants exhibited variations in the green color between light, medium and dark. According to Neitzke et al. (2010), genotypes that 
associate contrasting foliage with the variation of fruit color are interesting for cultivation for ornamental purposes, as they are highly attractive. The accessions UNI 08 and UNI 79 obtained this variation, with light colored leaves and medium and dark colored fruits respectively (Table 3 ).

Table 3. Descriptors for leaves of Capsicum spp. according to the National Service of Protection of Cultivars. Janaúba-MG, Brazil, 2020.

\begin{tabular}{lllllll}
\hline Access & $\mathbf{2}$ & $\mathbf{4}$ & $\mathbf{5}$ & $\mathbf{6}$ & $\mathbf{7}$ & $\mathbf{9}$ \\
\hline Uni 01 & Upright & Short & Med & Med & Absent & Strong \\
Uni 03 & Upright & Short & Narrow & Dark & Med & Med \\
Uni 04 & Semi upright & Med & Narrow & Dark & Absent & Weak \\
Uni 05 & Semi upright & Short & Narrow & Dark & Absent & Weak \\
Uni 06 & Semi upright & Short & Narrow & Med & Absent & Weak \\
Uni 07 & Semi upright & Short & Narrow & Med & Absent & Weak \\
Uni 08 & Upright & Long & Wide & Clear & Absent & Weak \\
Uni 11 & Semi upright & Short & Narrow & Med & Weak & Absent \\
Uni 79 & Semi upright & Short & Narrow & Clear & Absent & Absent \\
\hline 2. Plant: stem position; 4. Leaf blade length; 5. Leaf blade width; 6. Leaf color; 7. Leaf anthocyanin coloration; 9. Leaf roughness. Equal
\end{tabular}

classes: 1. Anthocyanin coloration in the hypocotyl: absent; 3 . Intensity of anthocyanin coloration of nodes: absent; 8 . Hairiness: absent.

Regarding the color of the leaves, the plants exhibited variations in the green color between light, medium and dark. According to Neitzke et al. (2010), genotypes that associate contrasting foliage with variation of fruit color are sought after for cultivation for ornamental purposes, as they are highly attractive. The accessions UNI 08 and UNI 79 obtained this variation, with light colored leaves and medium and dark colored fruits, respectively (Table 3 ).

Regarding the length and diameter of the fruit, the UNI 08 accession was classified differently from the others, classified as very long $(108.94 \mathrm{~mm})$ and very thick $(43.82 \mathrm{~mm})$, respectively (Table 4). The accessions UNI 06 and UNI 07 were classified as short with variations from 36.18 to $44.1 \mathrm{~mm}$, whereas the other accessions showed similarity in the length of the fruits, all of which were considered to be very short varying from 11.24 to $32.17 \mathrm{~mm}$.

The greatest amount of fruit is a desirable characteristic for peppers with ornamental potential, especially when associated with different ripening stages. The trend is that the smaller the size of the fruit, the greater the number of fruit produced by a pepper plant (Rodrigues et al., 2016). However, as for the size of the fruit, which involves length and width, there is a range of options to be explored in ornamental peppers, since different formats tend to please different audiences, increasing the sales possibilities.

The accessions UNI 03, UNI 05 and UNI 11 obtained dark purple color before maturation. The other accessions have a greenish-white to green color, of medium to dark intensity (Table 4). The color of the fruit in the immature stage is controlled by an allele series, however, it is still unknown which type of interaction occurs between them, nor the amount of genes that are related in determining this character (Nascimento, 2013).

Since the fruit is one of the main attractions for the consumer, this variation in color during the ripening phase arouses interest in the ornamental market. The presence of a greater number of colors, during the fruit ripening process, increases its aesthetic value, and this variation of colors simultaneously in the same plant arouses interest for decorative purposes (Neitzke et al., 2010; Silva et al., 2017). 
The UNI 06 accession was the only one distinct from the other accessions in terms of color at maturity, with yellow color. The yellow color at the stage of ripe fruits in Capsicum is of recessive genetic inheritance to red and controlled by a single y (yellow) gene (Boswell, 1937). The other accessions expressed a red color during maturation. Both colors, red and yellow, in the ripe fruits allow the contrast with the leaves, which are interesting to the ornamental market. The exuberance of the colors of the pepper fruits and their great variability allow the insertion of these genotypes in the production of ornamental preserves, red and yellow liquid sauces and in ornamentation (Finger et al., 2012).

According to Neitzke et al. (2010), fruits that reach an intense red color in the final stage of maturation and contrast with the foliage are the most desirable for ornamental purposes. And at each stage in ripening, the color of the fruit can match certain decorative items and the set of colors can function as the main decorative object. In the United States, for example, there are ornamental pepper cultivars launched and identified as 'Christmas Lights'. In these cultivars, were joined the shapes of the rounded fruits with the different colors, obtained in the fruit in the stages of maturation, that arouse interest the American public (Stommel et al., 2018).

The accessions UNI 03, UNI 04, UNI 05 and UNI 06 exhibited a rounded apex shape, while the other accessions presented an acute apex shape (Table 4). For fruit texture, all accessions were classified as smooth (Table 4). According to Ribeiro (2012), the apex of fruits combined with their texture is of great relevance in the choice of an ornamental arrangement of pepper by the consumer, with those with a pointed apex and smooth texture being the most appreciated.

Table 4. Descriptors for fruits of Capsicum spp. according to the National Service of Protection of Cultivars. Janaúba-MG, 2020.

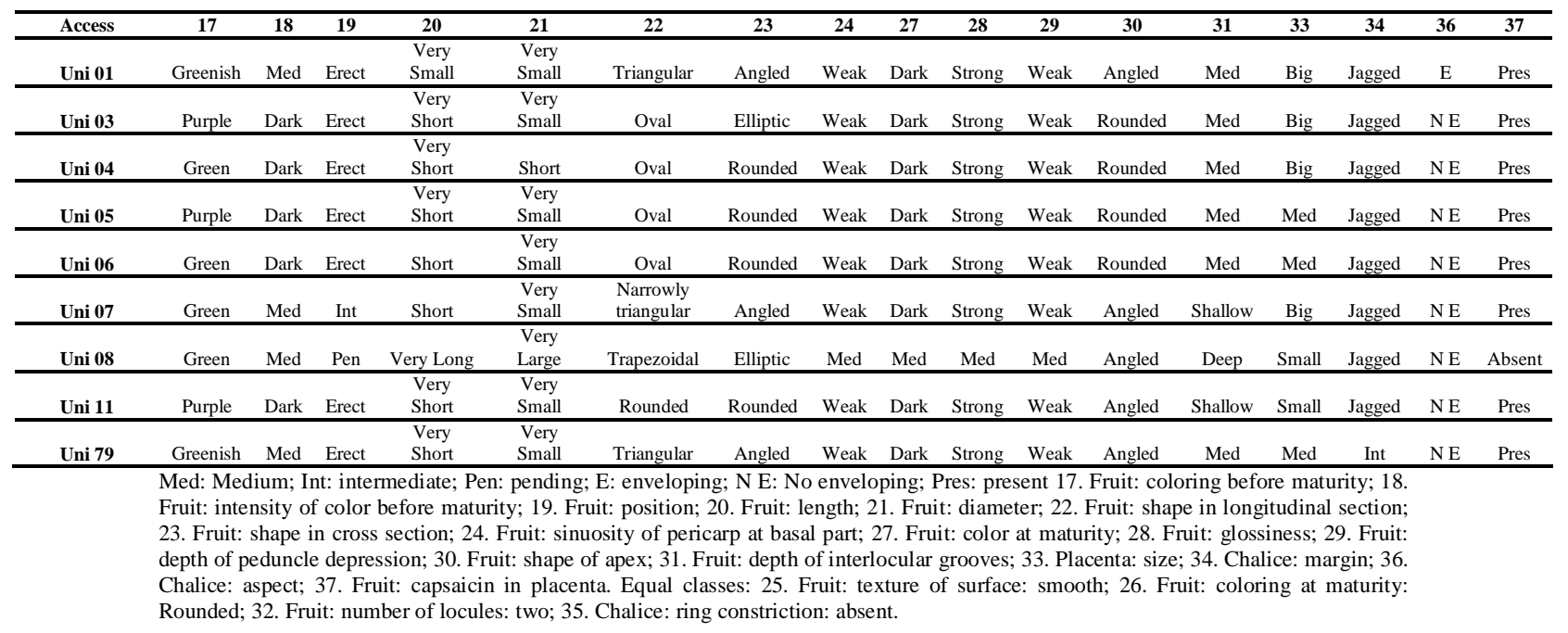

Regarding the characters related to the shape of the fruits, more precisely as to the predominant shape of the longitudinal section of the fruit and the predominant shape of the 
cross section, great genetic variability was observed (Table 4). Such characteristics are important, since the variety of the shape of the fruits is of ornamental interest. In Capsicum, in general, a great variation in the fruits is observed, be it in the formats, sizes, colors and flavors of the fruit, as well as, in the different degrees of pungency, plant architecture and nutritional composition (Baral and Bosland, 2002; Rodrigues et al., 2016). However, the number of cultivars available which explore such characteristics is still small, showing a niche market that can be explored in breeding programs.

There was no annular constriction in the cup in any accession (Table 4). This absence is related to genotypes of the species $C$. annuum, being also considered in the distinction between species. Several authors state that the main morphological distinction between $C$. chinense and the other cultivated species, besides of the color of the corolla, is a ring constriction located in the cup in its union with the pedicel (Carvalho et al., 2003; Rodrigues et al., 2016).

Only the UNI 08 accession did not have capsaicin in the placenta (Table 4). The pungency of Capsicum species is an important commercial attribute, which is one of the requirements to determine the commercial quality of products in which pungency is an attribute (Domenico et al., 2012). Pungency does not interfere in the ornamental market, since the demand is limited to characters that give aesthetic value, such as color and size. Accessions without capsaicin have the potential for ornamental use in vases and gardens (Lannes, 2005). This is because, non-pungent types may be ideal for consumers who have children in their homes, that is, consumers who do not want their children to have contact with pungent fruits. Pungent types, on the other hand, stand out in the fields of pharmacology, neurology and food, mainly because the capsaicinoids of the fruits are characterized by having a high biological activity (Paulus et al., 2017).

The dendrogram obtained via the genetic dissimilarity matrix, considering all the morphological variables, simultaneously, presented a cophenetic correlation coefficient of $93 \%$ (Figure 2). Dendrograms with CCC less than $70 \%$ would indicate the inadequacy of the grouping method to summarize the data set information. In this sense, the UPGMA method obtained a better fit between the graphic representation of the genetic dissimilarity and its original matrix. Several authors have confirmed the efficiency of the UPGMA method compared to the others available for analysis of this type. According to Gomes et al. (2019) the UPGMA grouping was more efficient by the co-phenetic and 2-norm correlation analyzes, indicating an agreement between the two methods.

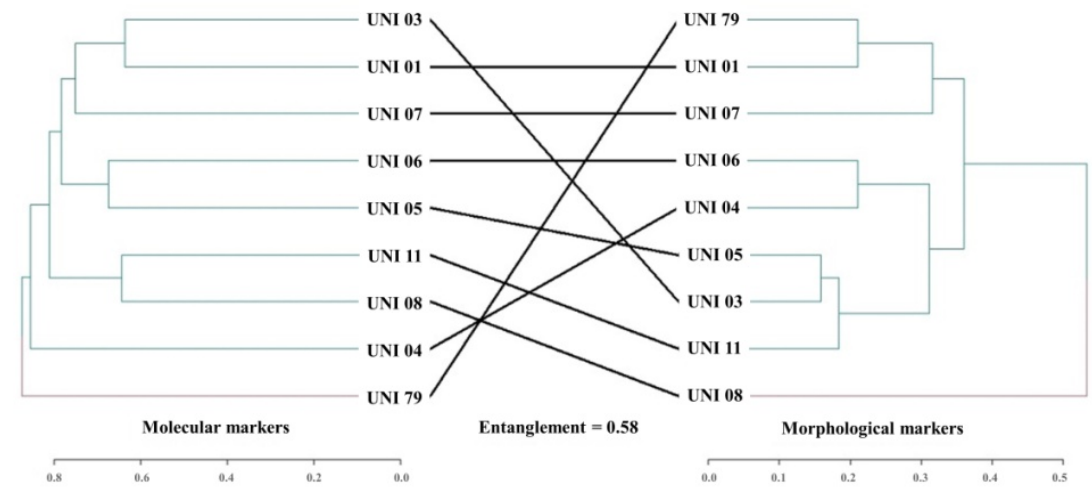

Figure 2. Dendrogram obtained by the UPGMA hierarchical method based on a genetic dissimilarity matrix using Jaccard and Gower analysis of molecular and morphological descriptors in nine accessions of ornamental peppers. 
Considering a cutoff point around $45 \%$ of dissimilarity, it was possible to obtain two distinct groups, formed from the genetic variability between accessions. The first group was composed only by the UNI 08 accession. The characteristics related to the length, diameter, shape of fruits and leaves combined with the absence of capsaicin, contributed to this result. This accession has characteristics similar to pepper, thus arousing interest in the ornamental market that seeks products that serve the consumer of this type of plant, such as non-pungent fruits combined with the typical beauty of ornamental peppers (Viñals et al., 1996). The distinction of this accession compared to the others, entitles it to be one of the possible parents in breeding programs of the species for ornamental and conventional purposes.

\section{Molecular approach}

The dendrogram obtained by the molecular analysis obtained a CCC of $84 \%$ (Figure 2). High genetic dissimilarity is observed between the evaluated accessions. It was not possible to distinguish the accessions of $C$. annuum var. glabriusculum from the others based on molecular analysis. It is important to report that the markers used to detect genetic dissimilarity are not specific for the morphological characters used for this purpose.

The molecular analysis allowed to detect greater dissimilarity between the accessions in relation to the morphological descriptors considered. Although this result is expected, considering that the number of molecular marks is substantially higher than the morphological ones, its quantification becomes important for better identification of promising parents in obtaining hybrids with greater potential heterotic effect to be used in breeding programs ornamental improvement programs of Capsicum. It is important to highlight the contribution of molecular markers to studies of genetic dissimilarity among Capsicum species, which are increasingly popular for this purpose. (Cardoso et al., 2018; Moreira et al., 2018; Jesus et al., 2019).

Molecular evaluation proved to be a tool with great potential for detecting the distinction between evaluated accessions of a Capsicum AGB. The addition of molecular tools to help distinguish between possible parents is useful, considering the need for detection in terms of morphological evaluation of undetected genetic variability. However, the use of this tool requires certain precautions, both in the choice of markers and in the interpretation of results. The joint analysis of the two sources of information, genotypic and phenotypic, can be considered the best way to prove the distinction.

\section{Association between morphological and molecular data}

By observing the associated dendrograms, there is a high association between them when considering the accessions of UNI 01, UNI 06 and UNI 07, facilitating the understanding of their dissimilarity in relation to different descriptors (Figure 2). It is noteworthy the low association regarding the UNI 79 accession which, for the morphological descriptors, showed a high level of similarity in relation to the others, while for the molecular ones the opposite was observed. This result expresses the importance of associating different ways of detecting genetic dissimilarity between accessions of an AGB, since only one type of approach, be it molecular or morphological, can indicate very contrasting results. The lack of association between morphological and molecular 
approaches was detected in okra landraces [Abelmoschus esculentus (L.) Moench], by Massucato et al. (2020). In this case, the authors associated the lack of relationship between the groups formed and their geographical origin, concluding that the cluster analysis was ineffective in detecting evaluated relationships.

A more detailed description can be made considering only the groups formed by the analysis of the morphological descriptors, mainly because in this work, such descriptors were discussed individually. The approach to be adopted here takes these groups into account. Simultaneously, it seeks to associate with the results obtained by molecular analysis. Mainly because it detects dissimilarity directly in the individual's genetic makeup and which, in many cases, cannot be detected with morphological evaluations.

With a $30 \%$ cut in dissimilarity, in the dendrogram of morphological descriptors, it was possible to form five groups of accessions (Figure 2). Group 1 is made up of UNI 08 accession and has already been discussed in previous paragraphs. The second group consists of accessions UNI 03, UNI 05 and UNI 11. These accessions were similar for fruit descriptors such as, color before maturation, color, and intensity at maturity, with purple color before maturation and red color during maturation. It is observed that there is no similarity between these accessions when considering the molecular descriptors (Figure 2). In these, such an association is reached at a level of $65 \%$ of genetic dissimilarity.

The third group composed by the accessions UNI 04 and UNI 06 are similar considering the fruit characters as the predominant shape of the longitudinal and transversal section, depth of the interlocular grooves and thickness of the pericarp. In these accessions, from the molecular descriptors considered, a high dissimilarity was observed, above $80 \%$. This result confirms, once again, how much two different methods of evaluation and detection of genetic dissimilarity can lead to different considerations and inferences about the evaluated accessions. At this point, there is greater interest in the morphological descriptors, since, in most cases, they are associated with characters of commercial interest.

It is noteworthy that in plants with ornamental purposes the thickness of pericarp is not a feature of great importance as for peppers and bell peppers for fresh consumption. For these the greater thickness to be related to greater mass and productivity at the time of commercialization, while for ornamentals, the fruits of greater thickness are not necessarily preferable, but for the beauty expressed by them (Blat et al., 2007). However, according to Ferrão et al. (2011) this characteristic must be considered, directly associated with the quality of the fruit, in addition to being related to the longer time of commercialization of the same.

The fourth group was composed only by the UNI 07 accession, which presented the main divergence from the other accessions, due to characters such as its predominant shape in the narrow triangular longitudinal section. According to Carvalho et al. (2006), in the ornamental plant market, fruit shapes are of great importance, as they promote contrasts with the leaves of the plants, expressing softness or aggressiveness to the ornamental arrangement. It is observed that, for molecular descriptors, such genetic dissimilarity in relation to other accessions was detected at the level of $65 \%$, showing greater dissimilarity by this evaluation method.

The fifth group gathered the accessions UNI 01 and UNI 79 which are similar for several characters, among them the length of fruits. Pepper genotypes with small fruits are indicated in pepper improvement programs as they stand out in the plant (do Rêgo 2016). However, it is seen that larger fruits can be explored in this market, especially when looking 
to associate beauty of plants and consumption of fruits. Such accessions, evaluated molecularly, showed high genetic dissimilarity, above $80 \%$ (Figure 2).

The use of the largest amount of information associated with the evaluation of the largest number of characters, be it morphological or molecular, allows a more complete and accurate description of an accession. The sum of this information makes it easier to indicate parents for breeding programs, in order to unite, create and explore the genetic variability associated with characters of interest in the ornamental plants market. All information collected must be processed and considered by the breeder for the planning of an ornamental pepper breeding program. With the accessions evaluated here, it was possible to observe potential parents for several characteristics of interest and, genetic variability among them, which can be explored.

The different methods of evaluation, for distinguishing between species and detecting genetic variability can be contrasting in their results. Thus, if possible, they should be carried out concurrently. The exploration of morphological and molecular information leads to more reliable inferences regarding the genetic dissimilarity present between accessions of a germplasm bank.

\section{ACKNOWLEDGMENTS}

This research was supported by the State University of Montes Claros and financed by the Brazilian National Council for Scientific and Technological Development (CNPq) and the Minas Gerais Research Support Foundation (Fapemig).

\section{CONFLICTS OF INTEREST}

The authors declare no conflict of interest.

\section{REFERENCES}

Baral JB and Bosland PW (2002). An updated synthesis of the Capsicum genus. Capsicum eggplant News. 21: 11-21. Blat SF, Braz LTE and Arruda ADS (2007). Avaliação de híbridos duplos de pimentão. Hort. bras. 25: 350-354.

Boswell VR (1937). Improvement and genetics of tomatoes, peppers, and eggplant. In: USDA (Yearbook of Agriculture, ed.). Government Printing Office, Washington, USA.

Cardoso R, Ruas CF, Giacomin RM, Ruas PM, et al. (2018). Genetic variability in Brazilian Capsicum baccatum germplasm collection assessed by morphological fruit traits and AFLP markers. PloS one. 13: e0196468.

Carvalho ICC, Bianchetti LB, Bustamante PG and da Silva DB (2003). Catálogo de germoplasma de pimentas e pimentões (Capsicum spp.) da Embrapa Hortaliças. Brasília: Embrapa Hortaliças.

Carvalho SD, Bianchetti LDB, Ribeiro CDCE and Lopes CA (2006). Pimentas do gênero Capsicum no Brasil. Brasília: Embrapa Hortaliças.

Costa GN, da Silva BMP, Lopes ACA, Carvalho LCB, et al. (2019). Selection of pepper accessions with ornamental potential. Rev. Caatinga. 32: 566-574.

Cruz CD (2016). Genes Software estendido e integrado ao R, Matlab e Selegen. Acta Sci. 38: 547-552.

da Luz PB, dos Santos AAB, Ambrosio VC, Neves LG, et al. (2018) Selection of indexes to evaluate the genetic variability aiming ornamental use of peppers accessions. Ornam. Hortic. 24: 7-11.

do Rêgo ER, do Rêgo MM and Finger FL (2016). Production and Breeding of Chilli Peppers (Capsicum spp.). 1. ed. Springer.

dos Santos Pessoa AMS, do Rêgo ER, de Carvalho MG, dos Santos Pessoa CA, et al. (2018). Genetic diversity among accessions of Capsicum annuum L. through morphoagronomic characters. Genet. Mol. Res. 17: gmr16039883.

dos Santos Pessoa AMS, do Rêgo ER, da Silva APG, de Mesquita JCP, et al. (2019a). Genetic diversity in F3 population of ornamental peppers (Capsicum annuит L.). Rev. Ceres. 66: 442-450.

dos Santos Pessoa AM, do Rego ER, dos Santos CAP, de Carvalho MG, et al. (2019b). Inheritance of seedling and plant traits in ornamental pepper (Capsicum апnиum). Genet. Mol. Res. 18: gmr18120. 
Domenico CI, Coutinho JP, Godoy HT and Melo AMT (2012). Caracterização agronômica e pungência em pimento de cheiro. Hort. bras. 30: 466-472.

Doyle JJ and Doyle JL (1990). Isolation of plant DNA from fresh tissue. Focus. 12: 13-15.

Ferrão LFV, Cecon PR, Finger FL, Silva FF, et al. (2011). Divergência genética entre genótipos de pimenta com base em caracteres morfo-agrônomicos. Hort. bras. 29: 354-358.

Finger FL, Rêgo ER, Segatto FB, Nascimento NFF, et al. (2012). Produção e potencial de mercado para pimenta ornamental. Informe Agropecuário. 33: 14-20.

Gomes GP, Baba VY, dos Santos OP, Sudré CP, et al. (2019). Combinations of distance measures and clustering algorithms in pepper germplasm characterization. Hort. Bras. 37: 172-179.

Jesus RD, Santos GDN, Piccin AS, Balsalobre TW, et al. (2019). Characterization of pepper accessions using molecular markers linked to pungency and SSR. Hort. bras. 37: 152-160.

Lannes SD (2005). Diversidade em Capsicum chinense: Análise química, morfológica e molecular. Doctoral dissertations. Universidade Federal de Viçosa, Viçosa. Available at [http://www.locus.ufv.br/handle/123456789/10542].

MAPA (2017). Ministério da Agricultura, Pecuária e Abastecimento/Registro Nacional de Cultivares - RNC. 07 feb 2017. Available at [http://sistemas.agricultura.gov.br/snpc/cultivarweb/cultivares_registradas.php]. Accessed 12 February 2020.

Massucato LR, Nakamura KK, Ruas PM, Zeffa DM, et al. (2020) Genetic diversity among Brazilian okra landraces detected by morphoagronomic and molecular descriptors. Acta Sci. Agron. 42: e43426.

Melo LF, Gomes RLF, Silva VB, Monteiro ER, et al. (2014). Potencial ornamental de acessos de pimenta. Cienc. Rural. 44: 2010-2015.

Moreira AFP, Ruas PM, de Fátima Ruas C, Baba VY, et al. (2018). Genetic diversity, population structure and genetic parameters of fruit traits in Capsicum chinense. Sci. Hortic. 236: 1-9.

Moreira GR, Caliman FRB, Silva DJH and Ribeiro CSC (2006). Espécies e variedades de pimenta. Informe Agropecuário. 27: 16-29.

Nascimento NFF (2013). Heterose e diversidade genética em híbridos intra e interespecíficos de pimenteiras ornamentais (Capsicum spp.). Master's thesis. Universidade Federal de Viçosa, Viçosa. Available at [http://locus.ufv.br/handle/123456789/4808].

Neitzke RS, Barbieri RL, Rodrigues WF, Corrêa IV, et al. (2010). Dissimilaridade genética entre acessos de pimenta com potencial ornamental. Hort. bras. 28: 47-53.

Paulus D, Zorzzi IC, Rankrape F, Paula FM, et al. (2017). Harvest seasons and pruning management in pepper: production and pungency of the fruits. Hort. bras. 35: 434-439.

Pickersgill B (1991). Cytogenetics and evolution of Capsicum L. In: Chromosome engineering in plants: genetics, breeding, evolution, part B (Tsuchiya T, Gupta PK, eds.). Amsterdam: Elsevier.

Pickersill B (1997). Genetic resources and breeding of Capsicum spp. Euphytica. 96: 29-133.

Ribeiro C, Reifschneider F, Carvalho S, Bianchetti L, et al. (2020). Embrapa's Capsicum Breeding Program-looking back... into the future. Crop Breed Genet. Genom. 2: e200001.

Ribeiro WS (2012). Avaliação de substratos e poda na produção de pimenteira ornamental. Master's thesis. Universidade Federal de Viçosa, $\quad$ Viçosa. Available at [https://www.locus.ufv.br/bitstream/handle/123456789/4580/texto\%20completo.pdf?sequence=1\&isAllowed=y].

Rodrigues R, Bento CS, Pimenta S and Sudré CP (2016). Melhoramento de Pimentão e Pimentas. Melhoramento de hortaliças (In: Nick C, Borém A, ed.). Viçosa, MG.

Santos RMC (2012). Variabilidade genética, controle genético e avaliação de características de pimenteiras ornamentais (Capsicum аппиит). Master's thesis. Universidade Federal de Viçosa, Minas Gerais. Available at [http://locus.ufv.br/handle/123456789/4762].

Silva LRA, Rodrigues R, Pimenta S, Correa JWS, et al. (2017). Inheritance of bacterial spot resistance in Capsicum aпnиит var. anпиит. Genet. mol. Res. 16: gmr16029631.

Stommel JR and Bosland PW (2007). Ornamental pepper. In: Flower Breeding and Genetics (Anderson NO,eds). Springer, Dordrecht.

Stommel JR, Kozlov M and Griesbach RJ (2018). Ornamental Pepper (Capsicum annuиm L.) Cultivars Comprising the Christmas Lights Cultivar Series. Hort. Sci. 53: 391-394.

Sudré CP, Cruz CD, Rodrigues R, Riva ER, et al. (2006). Variáveis multicategóricas na determinação da divergência genética entre acessos de pimenta e pimentão. Hort. Bras. 24: 88-93.

Viñals FN, Ortega RG and Garcia JC (1996). El cultivo de pimientos, chiles y ajies. Madrid: Mundi Prensa.

Walter R, Carvalho VS, Generoso AL, Campbell G, da Cunha M, et al. (2019). Overcoming post-zygotic hybridization barriers in Capsicum annuит var. апnиит. Sci. Hort. 246: 227-236. 